кандидат педагогічних наук

(Житомирський державний університет імені Івана Франка) inesanovicka@gmail.com ORCID: 0000-0003-0780-0580

\title{
ПОЕТАПНА МЕТОДИКА ФОРМУВАННЯ ПРОФЕСІЙНИХ УМІНЬ МАЙБУТНІХ УЧИТЕЛІВ ПРИРОДНИЧО-МАТЕМАТИЧНИХ ДИСЦИПЛІН У ПРОЦЕСІ РОЗВ'ЯЗУВАННЯ ПРОФЕСІЙНО-ПЕДАГОГІЧНИХ ЗАДАЧ
}

\begin{abstract}
У статті розглядається проблема формування професійних умінь майбутніх учителів природничоматематичних дисциплін у процесі розв 'язування професійно-педагогічних задач; представлено та описано шляхи реалізаиії поетапної методики формування професійних умінь майбутніх учителів у процесі розв 'язування професійно-педагогічних задач. У статті обгрунтовано, що застосування поетапної методики формування професійних умінь у процесі розв'язування професійно-педагогічних задач має ефективний вплив на формування професійної компетентності майбутніх фахівиів.
\end{abstract}

Ключові слова: професійні уміння, формування професійних уміння, професійно-педагогічні задачі, прочес розв'язування професійно-педагогічних задач, етапи розв'язування професійно-педагогічних задач, методика формування професійних умінь.

Постановка проблеми у загальному вигляді та ї̈ зв'язок із важливими науковими $i$ практичними завданнями. Важливою умовою модернізації освіти України у XXI столітті $\epsilon$ підготовка педагогічних та науково-педагогічних працівників як висококваліфікованих педагогів, здатних творчо, креативно мислити та знаходити рішення будь-яких складних завдань. Специфіка діяльності вчителя природничо-математичних дисциплін в сучасних умовах вимагає від нього компетентного мислення, спостережливості, уміння планувати, здійснювати та аналізувати педагогічний процес, який являє собою нескінченний ряд педагогічних задач, спрямованих на досягнення загальної мети - формування особистості учня, його світогляду, переконань, свідомості, поведінки. У зв'язку з цим важливого значення набуває підготовка майбутнього вчителя природничо-математичних дисциплін до конструктивного розв'язання різноманітних професійно-педагогічних задач.

Аналіз основних досліджень і публікацій із зазначеної проблеми. Останніми роками велика увага 3 боку науковців приділяється проблемі підготовки майбутніх фахівців. Зокрема, проблемою підготовки майбутніх педагогів до професійної діяльності займались такі вчені, як О. С. Антонова, Л. В. Брескіна, О.А.Дубасенюк, М. В. Золочевська, Н. М. Кириленко, О.М.Пєхота; шляхи формування професійної педагогічної майстерності та творчої особистості вчителя знаходять своє відображення у роботах І. А. Зязюна, Н. В. Кічук, С. О. Сисоєвої та ін.; проблемі розв'язування педагогічних задач та ситуацій та етапам їх розв'язання приділяли увагу О. О. Біляковська, Б. З. Вульфов, Н. В. Кузьміна, А. І. Кузьмінський, Ю. Н. Кулюткіна, Л. Ф. Спірін, І. К. Унгурян.

Формулювання мети і завдань статті. 3 огляду на вищезазначене, метою статті $\epsilon$ опис поетапної методики формування професійних умінь (ПУ) майбутніх учителів природничо-математичних дисциплін у процесі розв'язування педагогічних задач.

Виклад основного матеріалу з обгрунтуванням отриманих наукових результатів. У процесі розробки поетапної методики формування професійних умінь у майбутніх учителів природничоматематичних дисциплін у процесі розв'язування педагогічних задач ми орієнтувались на концепцію змісту освіти, розроблену І.Я. Лернером, згідно 3 якою, зміст освіти визначається знаннями (інформацію), способами діяльності, досвідом творчої діяльності і досвідом емоційно-ціннісного ставлення до діяльності [1]. Навчальні завдання спрямовувалися на формування професійних умінь у майбутніх учителів природничо-математичних дисциплін у процесі розв'язування педагогічних задач. Стрижень розробленої поетапної методики визначали навчально-практичні завдання, що містили дослідницькі та проблемні елементи, вимагали від студентів виконання ролі експериментаторів, спонукали до творчого опановування раціональних способів застосування знань на практиці.

Організація навчально-пізнавальної діяльності студентів спрямовувалася на розвиток уміння аналізувати та досліджувати як педагогічні задачі-ситуації, так і власної дії у них (такий підхід реалізовується у ході рефлексивного навчання). Це сприяло розвитку у студентів таких професійно значущих особистісних якостей, як критичність, аналітичність, здатність до самоаналізу та самооцінки.

Розроблена нами поетапна методика формування ПУ майбутніх учителів природничо-математичних дисциплін у процесі розв'язання професійно-педагогічних задач передбачала: дослідження основ конструювання конкретних педагогічних рішень; організацію активної взаємодії між студентами у процесі пошуку рішення; співвіднесення загальних теоретичних положень зі зразками та варіантами конкретних педагогічних рішень, в яких вони знайшли своє втілення. Так, поетапна методика 
формування ПУ у студентів у процесі розв'язання професійно-педагогічних задач включала в себе комплекс організаційних форм, методів і прийомів психолого-педагогічної підготовки: лекційні та семінарські заняття; практичні заняття; індивідуально-консультаційна робота; моделювання та аналіз типових педагогічних ситуацій; розв'язування психолого-педагогічних задач; групові дискусії; сюжетнорольові ігри; психотехнічні вправи; виконання спеціальних завдань під час проходження педагогічної практики.

Практикувалося, зокрема, застосування, так званих, мікроситуацій, що подавалися в лаконічній формі і описували суть педагогічного конфлікту з схематичним окресленням обставин. Такі ситуації, як правило, застосовувалися на лекційних заняттях, що дозволяло внести в навчальний процес елементи проблемності, спонукало студентів до формулювання самостійних висновків і узагальнень, загострювало їх увагу на ключових моментах навчального матеріалу. Мікроситуації використовувались також в якості прикладів до лекційного матеріалу.

У ході навчального процесу використовувалися задачі-проблеми, що характеризуються значним мотиваційним потенціалом. Студентам пропонувалося не тільки проаналізувати педагогічні обставини, що склалися, але й прийняти обгрунтоване рішення. Це ситуаційні задачі, які суттєво відрізняються від звичайних навчальних задач-вправ. У навчальній задачі-вправі завжди $є$ чітко сформульована умова (що дано) і вимога (що треба знайти). В описі ситуаційної задачі немає, як правило, ні того, ні іншого. У реальних педагогічних ситуаціях вчителеві, передусім, треба розібратися в обставинах їх виникнення, визначити ії сутність. Лише після педагог може визначити відоме і те, що треба з'ясувати для прийняття обгрунтованого рішення.

Уміння формулювати задачу, що вимагає розв’язання в конкретних обставинах, одне 3 найважливіших у структурі професійної діяльності педагога будь-якої спеціальності, зокрема, вчителя природничо-математичних дисциплін. Саме для його розвитку і вдосконалення призначені, насамперед, ситуаційні задачі. За їх допомогою створювалися умови для самостійного визначення студентами, що "дано" і що "вимагається знайти". Ситуаційна задача може мати декілька варіантів розв'язання в різній або однаковій мірі близьких до оптимального і прийнятного в конкретних умовах. Саме ця особливість ситуаційних задач враховувалася в побудові основної частини заняття-дискусії, в якій порівнювалися і обговорювалися різноманітні варіанти розв'язання професійно-педагогічної задачі.

3 огляду на те, що ситуаційні задачі далеко не завжди вирішуються за відомим алгоритмом, їх застосування в навчальному процесі забезпечує самостійне розроблення алгоритму розв'язання типових педагогічних задач майбутніми учителями. Від студента вимагалося не просто знайти розв'язок задачі, а визначити раціональні методи іiі аналізу і шляхи розв'язання всіх проблем подібного типу. Таким чином, розв'язання ситуаційних задач давало змогу студентам переходити від окремого випадку до певних висновків і узагальнень.

Методика застосування ситуаційних задач вимагала спочатку від студента аналізувати матеріал, самостійно намагаючись виділити в ньому проблему та всю необхідну для ії розв'язання інформацію. Після цього обговорювали висновки і пропозиції в невеликих групах по 4-6 осіб, студенти виробляли спільні висновки або рішення. Всі варіанти розв'язку проблеми виносилися на загальну дискусію всієї групи з обговоренням різних точок зору на проблему і варіанти іiі розв'язання. Завдання кожного студента полягало в тому, щоб аргументовано довести обгрунтованість свого рішення і оцінити варіанти, запропоновані товаришами. У результаті дискусії майбутні фахівці приходили до колективно виробленого рішення або зупинялися на 2-3 рівноцінних варіантах.

Заняття 3 використанням конкретних професійно-педагогічних задач суттєвим чином активізували пізнавальну діяльність студентів. Від них вимагалось не просто знайти розв'язок певної задачі, але й обгрунтувати і презентувати у ході групової дискусії. На таких заняттях майбутні учителі природничоматематичних дисциплін виконували ряд операцій, у процесі яких вироблялись професійно важливі вміння і навички, в тому числі, навички роботи з інформацією, уміння обгрунтовувати свої міркування, організовувати процес колективного розв'язання проблеми, використовуючи знання i досвід, накопичений іншими фахівцями, тощо.

У процесі впровадження поетапної методики нами широко застосовувалися ділові педагогічні ігри, що $є$ ефективним методом моделювання педагогічних ситуацій та розв'язанням педагогічних задач. Ділові педагогічні ігри формують у майбутніх учителів комплекс фахових знань, умінь і навичок, необхідних для вирішення педагогічних задач. Вони створюють умови для обміну знаннями й досвідом, спонукають до активності в їх надбанні, розвивають інтерес до творчості.

Під час використання ділових ігор ставилися такі завдання: узагальнити набуті знання, досвід; пов'язати теорію з практикою; формувати вміння моделювати педагогічні ситуації різних типів; поглибити інтерес, любов до педагогічної професії.

У процесі моделювання шкільного середовища педагогічна ділова гра дає змогу відтворити відносини суб'єктів та об’єктів навчання і виховання поза умовами їхньої реальної дійсності. За таких умов на навчальних заняттях у ВНЗ надається можливість змоделювати окремі елементи навчально-виховного 
процесу, оцінити рівень професійної готовності студентів до виконання визначених педагогічних завдань.

Основним шляхом включення учасників гри у спільну пізнавальну діяльність і одночасно шляхом створення та розв'язання ігрових проблемних задач виступало діалогічне і полілогічне спілкування, у ході якого студенти виробляли індивідуальні та групові рішення, вчилися знаходити оптимальний вихід із складних педагогічних задач. Студент за таких умов виступає в ролі творчого дослідника, що змушує його шукати шляхи і способи вирішення проблеми на основі наявних знань.

Зберігаючи загальну ідею структури ділової гри, ми виділили такі іï елементи: мета гри; ігрова ситуація, що має педагогічну спрямованість; комплект ролей; правила гри; етапи гри (підготовчий, організаційний, ігрова діяльність, заключний) [2].

У результаті роботи ми побудували логічну схему ділової педагогічної гри, яка включає наступні етапи: підготовка до гри; планування гри; деталізація гри; проведення гри; аналіз гри. Після закінчення гри одному із студентів пропонувалося узагальнити методику ії підготовки і проведення та розкрити роль педагога в цій підготовці. Отже, ділова гра дає змогу студенту виявити себе не лише у виконанні ролі, а й в їі аналізі.

Варто зазначити, що ділова педагогічна гра та іiї ситуація мають відповідати рівню можливостей іiі учасників, що забезпечить досягнення очікуваного результату. Ігрова роль - це, насамперед, соціальна роль учителя, що виконує пародоксальну функцію бути одночасно організатором і рівноправним учасником навчально-виховного процесу. Сукупність ігрових правил орієнтує учасників гри на реалізацію поставлених завдань. Необхідно зазначити, що ділова гра не може повною мірою відтворити реальні життєві ситуації, пов'язані з майбутньою професійною діяльністю, вона трохи спрощує їх, але зберігає при цьому принципові моменти. Ігрові взаємодії учасників i ïх функції корегуються безпосередньо в процесі ігрової діяльності.

Таким чином, за допомогою ділових педагогічних ігор у майбутніх учителів поглиблюються їх знання, виробляються вміння, навички, розвиваються певні особистісні якості, що є критеріями формування основ професіоналізму.

Досягнення дидактичної мети ділової гри відбувається саме через якісний, усебічний, глибокий, кваліфікований аналіз, а, отже, це вимагає ретельної підготовки, так званої, карти спостережень. На навчальному ігровому занятті створюється атмосфера зацікавленості, природності, товариської взаємодопомоги - студенти ведуть колективний пошук правильного розв'язання. Окрім цього, у творчій ігровій атмосфері характери розкриваються повніше. Отже, викладачеві надаються великі можливості для вивчення рівня розвитку професійних, психологічних рис особистості студента. Порівняно з іншими методами ділова гра сприяє більшому наближенню до реальних умов, надає неоціненну допомогу студентам у подоланні природної для молодого педагога невпевненості у спілкуванні з дітьми. У діловій грі зникає страх прийняти неправильне рішення. Адже в цьому випадку можна "переграти" ситуацію 3 урахуванням зауважень і побажань товаришів та викладача.

Розроблена поетапна методика передбачала забезпечення зворотного зв'язку, який функціонував на основі прогностичної діагностики. Це давало можливість оперативно виявляти динаміку сформованості у студентів умінь розв'язувати педагогічні задачі, їхню готовність до самовиховання, адекватність самооцінок і їх трансформацію в процесі педагогічного впливу. При цьому ми керувалися положенням про взаємозв'язок частоти діагностування індивідуальних типологічних якостей особистості студента у процесі навчання й оптимальністю та своєчасністю здійснення його корекції. Одним 3 основних елементів розробленої поетапної методики є показники успішності формування ПУ у студентів у процесі розв’язання педагогічних задач, що передбачає позитивну динаміку розвитку педагогічного мислення i ріст рівня готовності до самовиховання.

Практичний досвід роботи у ВНЗ дозволяє стверджувати, що розвиток ПУ у студентів у процесі розв'язання професійно-педагогічних задач загалом збігається із етапами їх професійного становлення, визначеними Н. В. Кузьміною [3]. Це репродуктивний, адаптивний, моделюючий, творчо-дослідницький.

Професійне становлення майбутнього вчителя великою мірою залежить від проходження педагогічної практики. Так, під час проходження неперервної педагогічної практики студенти повинні були виконати певні завдання. Частині майбутніх учителів пропонувалося організувати у класі виховні години, іншим - організувати клас для гри на перерві, для проведення методик. Окрім цього, студенти організовували класи для прогулянок у парки, сквери. Під час проведення уроків з математики, фізики i т.д. під керівництвом учителя студентові необхідно було провести його за відповідним типом, організувати клас до виконання завдань, стежити за дисципліною.

Окрім цих завдань, при проходженні пасивної педагогічної практики студенти повинні були за відповідною карткою оцінити окремо діяльність вчителя і учнів на уроці, розв'язати педагогічну задачу за відповідним алгоритмом, оцінити рівень важливості професійних умінь, рівень сформованості таких умінь у себе, у вчителів-предметників, необхідності таких умінь при проведені кожного етапу уроку, при розв’язанні педагогічних задач. Такі ж завдання студенти отримували і при проходженні активної 
(навчальної) педагогічної практики.

До майбутнього вчителя природничо-математичних дисциплін під час навчальної практики висувались такі вимоги: а) завчасно підготувати необхідне обладнання; б) чітко визначитися 3 структурою уроку; в) спланувати навантаження і відпочинок тощо. Під час проходження практики студентам надавалися і теоретичні завдання, що спонукало не тільки до засвоєння, а й до використання набутих знань у практичній діяльності. Тому теоретичні і практичні заняття проводились у комплексі, що давало можливість формувати різні групи умінь.

Окрім уроків, які проводили і оцінювали студенти у ході педагогічної практики, важлива роль відводилася проведенню й аналізу семінарських занять в університеті. Окремі з них було побудовано у вигляді рольової гри, що сприяла розвиткові у них не лише інтелектуального, а й емоційного потенціалу студентів. Рольова гра допомагала кожному особисто знайти відповідь на питання, як реалізувати свій педагогічний задум. Як приклад, можна навести одне з занять, що проходило у вигляді рольової гри. Частина студентів була обрана спеціалістами психолого-педагогічної консультації. Вони повинні були вислуховувати, аналізувати і визначати шляхи виходу із конфліктної ситуації, що була запропонована відвідувачем (батьком, учнем, учителем), який звернувся за допомогою. Потім вони узагальнювали думки і найкращий варіант вирішення проблеми брали за основу. Ця гра створювала атмосферу, наближену до практичних умов діяльності фахівця, і дозволяла студентам відстоювати свою позицію. Конкретне практичне уявлення про майбутню діяльність складалося у студентів також за рахунок бачення себе в різних професійних ролях: практичного психолога, вчителя, молодого спеціаліста, директора школи.

Під час реалізації методики забезпечувались педагогічні умови, необхідні для успішного формування професійних умінь у майбутніх учителів природничо-математичних дисциплін у процесі розв'язування професійно-педагогічних задач. Зокрема, реалізація індивідуально-особистісного підходу, врахування особистої динаміки досягнень та індивідуальних особливостей студентів. Ефективним у цьому контексті виявилося застосування у навчальному процесі не окремих ізольованих проблемних завдань, а їх методично обгрунтованої системи. У цих умовах діяльність студентів набувала особистісної значущості, супроводжувалася яскравими переживаннями, радістю самостійного відкриття. Вона формувала також почуття власної гідності, що $є$ особливо важливим для майбутнього вчителя.

Створення атмосфери співпраці, співтворчості і взаємонавчання та залучення всіх студентів до творчого пошуку досягалося шляхом застосуванням різноманітних форм організації навчальнопізнавальної діяльності. Зокрема, для розв'язання навчальних завдань під час занять використовувалася робота студентів у парах, що передбачало реалізацію принципів взаємозв'язку і взаємовпливу. Взаємовплив реалізовувався шляхом залучення до розв'язування задач студентів, які досягли достатнього та високого рівня, формування ПУ, які допомагали іншим студентам, виконуючи при цьому фасилітативну функцію. Варто зазначити, що в процесі такої співпраці й особистого прикладу студенталідера, слабші студенти позитивно змінювали своє ставлення до навчання, майбутньої професійної діяльності.

Використання у навчальному процесі творчих завдань, які розвивали вміння самостійно визначати цілі, звільнятися від набутих у минулому стереотипів дозволило нам під час аналізу педагогічних задач на заняттях із психолого-педагогічних дисциплін використати такі види завдань: згадати і розповісти із свого власного досвіду педагогічну задачу; змоделювати декілька різних педагогічних задач за запропонованим розв'язком-зразком; змоделювати аналогічні професійні педагогічні задачі, які не мають розв'язку-зразка. Такі завдання сприяли розвитку у майбутнього вчителя здатності до розуміння варіативності дій у конкретних професійних ситуаціях, уміння критично підходити до використання різноманітних способів впливу на особистість школяра. Дотримання цих положень дозволило налагодити оптимальний професійно-особистісний контакт між групою, кожним конкретним студентом і педагогом.

Послуговуємося думкою, що розв'язання професійно-педагогічних задач належить до творчої діяльності, яка полягає у вирішенні цілої низки педагогічних завдань. Аналіз практики роботи шкіл та педагогічні спостереження свідчать, що розв'язуючи професійно-педагогічну задачу, учитель у багатьох випадках приймає "миттєве" рішення за схемою: виникнення ситуації - миттєве прийняття рішення. Такий спосіб реагування часто не забезпечує ефективного розв'язання педагогічних ситуацій [4].

3 огляду на творчий характер діяльності вчителя природничо-математичних дисциплін, формуванню ПУ у студентів у процесі розв'язання професійно-педагогічних задач сприяло також їх ознайомлення із загальним алгоритмом дій у складних обставинах. Алгоритмічний підхід створює можливість досить швидко оволодіти змістом педагогічних задач у ході їх розв'язання і послідовно аналізувати численні події. Важливою умовою успішного оволодіння способами розв'язання професійно-педагогічних задач, на нашу думку, була детальна фіксація та аналіз конкретних дій учнів і вчителя. На основі цього визначалася сутність педагогічних відносин та проектувалися можливі шляхи розв'язання задач.

Аналіз конкретних професійно-педагогічних задач у процесі навчання природничо-математичних 
дисциплін слугував для студентів інструментом дослідження і вивчення певної педагогічної проблеми, оцінки і вибору найбільш ефективних дій у навчально-виховному процесі в цілому. Ми враховували, що всі професійно-педагогічні задачі неможливо передбачити, тому наведений алгоритм їх розв'язання може постійно змінюватися і вдосконалюватися відповідно до специфіки задачі.

Важлива увага приділялася забезпеченню операціоналізації психолого-педагогічних знань майбутніх учителів природничо-математичних дисциплін, формуванню у них інтегрального уміння використовувати засвоєні теоретичні знання для аналізу запропонованих педагогічних задач та прийняття обгрунтованих і продуктивних педагогічних рішень.

Висновки та перспективи подальшого дослідження проблеми. Водночас, відкритою залишається проблема розробки проблемних технологій підготовки фахівців природничо-математичних дисциплін, що забезпечують розвиток у студентів професійного мислення, здатності розв'язувати завдання, максимально наближені до професійних.

\section{СПИСОК ВИКОРИСТАНИХ ДЖЕРЕЛ ТА ЛІТЕРАТУРИ}

1. Лернер И. Я. Процесс обучения и его закономерности / И. Я. Лернер. - М. : Знание, 1980. - 96 с.

2. Кузьмина Н. В. Основы вузовской педагогики : [учебное пособие для студ. ун-та] / Н. В. Кузьмина. - Л. : Изд-во ЛГУ, 1972. - 311 с.

3. Кузьмина Н. В. Методы системного педагогического исследования / Нина Васильевна Кузьмина. - Л. : Издво ЛГУ, 1980. - $172 \mathrm{c.}$

4. Ковальчук В. А. Методичні основи розв'язання соціально-педагогічних задач у процесі підготовки майбутніх учителів : дис. ... канд. пед. наук : 13.00.04 / Валентина Антонівна Ковальчук. - Житомир. - 2000. -189 с.

5. Кириленко Н. М. Педагогічні умови застосування комп'ютерних дидактичних ігор у фаховій підготовці майбутніх учителів математики й інформатики : автореф. дис. на здобуття наук. ступеня канд. пед. наук : спец. 13.00.04 "Теорія і методика професійної освіти"/ Н. М. Кириленко. - Вінниця, 2010. - 20 с.

6. Дубасенюк О. А. Професійна підготовка майбутнього вчителя до педагогічної діяльності : [монографія] / О. А. Дубасенюк, Т. В. Семенюк, О. С. Антонова. - Житомир : Житомир. держ. пед. ун-т, 2003. - 193 с.

\section{REFERENCES (TRANSLATED \& TRANSLITERATED)}

1. Lerner I. Ya. Protsess obucheniia i eho zakonomernosti [Learning Process and It's Principles] / I. Ya. Lerner. - M. : Znaniie, 1980. - $96 \mathrm{~s}$.

2. Kuz'mina N. V. Osnovy vuzovskoi pedahohiki [Fundamentals of Academic Pedagogics] : [uchebnoe posobiie dlia stud. un-ta] / N. V. Kuz'myna. - L. : Izd-vo LHU, 1972. - $311 \mathrm{s.}$

3. Kuz'myna N. V. Metody systemnoho pedahohicheskoho issledovaniia [Methods of Systemic Pedagogical Research] / Nyna Vasilievna Kuz'mina. - L. : Izd-vo LHU, 1980. - 172 s.

4. Koval'chuk V.A. Metodychni osnovy rozviazannia sotsial'no-pedahohichnykh zadach uprotsesi pidhotovky maybutnikh uchyteliv [Methodical Bases of Solving Social and Educational Problems in Preparing Future Teachers] : dys. ... kand. ped. nauk : 13.00.04 / Valentyna Antonivna Koval'chuk. - Zhytomyr. - 2000. - 189 s.

5. Kyrylenko N. M. Pedahohichni umovy zastosuvannia kompiuternykh dydaktychnykh ihor u fakhovii pidhotovtsi maibutnikh uchyteliv matematyky i informatyky [Pedagogical Conditions of Teaching Using Computer Games in Professional Training of Future Teachers of Mathematics and Computer Science] : avtoref. dys. na zdobuttia nauk. stupenia kand. ped. nauk : spets. 13.00.04 "Teoriia i metodyka profesinoi osvity"/ N. M. Kyrylenko. - Vinnytsia, 2010. $-20 \mathrm{~s}$.

6. Dubaseniuk O. A. Profesiina pidhotovka maybutnioho vchytelia do pedahohichnoi diial'nosti [Prospective Teachers' Vocational Training to Educational Work] : [monohrafiia] / O. A. Dubaseniuk, T. V. Semeniuk, O. Ye. Antonova. Zhytomyr : Zhytomyr. derzh. ped. un-t, 2003. - $193 \mathrm{~s}$.

\section{Новицкая И. В. Поэтапная методика формирования профессиональных умений будущцх учителей естественно-математических дисциплин в процессе решения профессионально-педагогических задач.}

В статье рассматривается проблема формирования профессиональных умений будущих учителей естественно-математических дисциплин в процессе решения профессионально-педагогических задач; представлены и описаны пути реализации поэтапной методики формирования профессиональных умений будущих учителей в процессе решения профессионально-педагогических задач. В статье обосновано, что применение поэтапной методики формирования профессиональных умений в процессе решения профессионально-педагогических задач имеет эффективное влияние на формирование профессиональной компетентности будущих специалистов.

Ключевые слова: профессиональные умения, формирование профессиональных умения, профессионально-педагогические задачи, прочесс решения профессионально-педагогических задач, этапы решения профессионально-педагогических задач, методика формирования профессиональных учений. 


\section{Novitska I. V. Gradual Methods of Forming Professional Skills of Prospective Teachers of Natural and Mathematical Disciplines in the Process of Solving Professional and Pedagogical Tasks.}

The article deals with the problem of forming professional skills of prospective teachers of natural and mathematical disciplines in the process of solving professional and pedagogical tasks. The main ways to implement the gradual methods of forming professional skills of prospective teachers of natural and mathematical disciplines in the process of solving professional and pedagogical tasks are presented and explained. On the basis of their comparison, it was found out that the most promising in the practice of higher education is the creation of a step-by-step methodology in which all components are identified and characterized. It intensifies the process of forming the professional skills of prospective teachers of natural and mathematical disciplines in the process of solving professional and pedagogical tasks.

The analysis of modern technology in higher education shows that the training of the prospective teacher of natural and mathematical disciplines is mainly based on the use of standard forms and teaching methods. The conducted research confirmed the assumption that the formation of professional skills of prospective teachers of natural and mathematical disciplines in the process of solving vocational and pedagogical tasks should be considered as an objective creative process of training specialists on the basis of a systematic approach. The author states that a gradual methodology of the formation of professional skills of prospective teachers of natural and mathematical disciplines in the process of solving pedagogical problems was developed and experimentally proved its effectiveness. A general conclusion is made concerning the results of the implementation of this methodology and students comprehend the essence of solving the problems and pedagogical tasks.

Key words: professional skills, formation of professional skills, professional and pedagogical tasks, the process of solving professional and pedagogical tasks, stages of solving professional and pedagogical tasks, the method of formation of professional exercises. 